The Historical Journal

http://journals.cambridge.org/HIS

Additional services for The Historical Journal:

Email alerts: $\underline{\text { Click here }}$

Subscriptions: Click here

Commercial reprints: Click here

Terms of use : $\underline{\text { Click here }}$

\title{
JOHN LILBURNE AND THE LONG PARLIAMENT
}

\section{J . T. PEACEY}

The Historical Journal / Volume 43 / Issue 03 / September 2000, pp 625 - 645

DOI: null, Published online: 16 January 2001

Link to this article: http://journals.cambridge.org/abstract_S0018246X99001302

How to cite this article:

J . T. PEACEY (2000). JOHN LILBURNE AND THE LONG PARLIAMENT . The Historical Journal, 43, pp 625-645

Request Permissions : $\underline{\text { Click here }}$ 
The Historical Fournal, 43, 3 (2000), pp. 625-645 Printed in the United Kingdom

(C) 2000 Cambridge University Press

\title{
JOHN LILBURNE AND THE LONG PARLIAMENT*
}

\author{
J. T. PEACEY \\ History of Parliament, London
}

\begin{abstract}
A вs тR A ст. This piece reinterprets the career of the Leveller, Fohn Lilburne, during the English Civil War, by re-examining the official sources pertaining to him, and the multitude of pamphlets written by himself and his enemies. The article recovers the chronology of Lilburne's story, by stripping away the layers of propaganda with which he later surrounded himself. It shows that he had powerful friends at Westminster, and that his tribulations were caused by political rivalries within Westminster rather than his development of a radical political theory. He is shown to have formed part of the 'Independent alliance' during the mid-I64os, although his protected position was eventually imperilled by the fracturing of this group after the end of the first Civil War. The aim is to improve not just our understanding of Lilburne, but the complexity of parliamentarian politics during the I64os.
\end{abstract}

A man of restless, boyling and unwearied spirit, condemned by his ungovernable temper to perpetual troubles, and quarrels with his superiors, and always opposing himself to the power that was uppermost. ${ }^{1}$

Scholarship concerning John Lilburne has arguably progressed little since John Nalson penned the above words in I 682, and few would now disagree that Lilburne was both 'ungovernable' and in 'perpetual' dispute with the powers under which he lived. Indeed, one recent scholar ascribed to him 'a psychology of confrontation and protest'. ' It is true that Lilburne was one of the 'puritan martyrs' of the I63os; tutored in illicit printing by Burton, Bastwick, and Prynne, and tortured like them on the pillory. ${ }^{3}$ It is also true that, as a godly hero, Lilburne received favourable treatment from the Long Parliament, where his release was effected through the efforts of Oliver Cromwell. ${ }^{4}$ Furthermore, it is undeniable that by the late I640s Lilburne had been transformed from hero into public enemy, as the leader of the Levellers, and the

\footnotetext{
* I am grateful to members of the seventeenth-century British history seminar at the Institute of Historical Research, and to Prof. John Morrill, Dr David Scott, and Dr Ian Roy for comments on an earlier draft of this article.

${ }^{1} \mathrm{~J}$. Nalson, An impartial collection (2 vols., i $682_{2-3}$ ), I, p. 5 1 2. All pre-1 800 works were published in London unless otherwise stated. The standard biographical account of Lilburne, on which I have drawn heavily, is P. Gregg, Free-born Fohn (London, I 986).

${ }^{2} \mathrm{M}$. Tolmie, The triumph of the saints (Cambridge, i977), pp. 146-7.

${ }^{3} \mathrm{~J}$. Lilburne, The Christian man's triall (164I); PRO, PC 2/49, fos. $55 \mathrm{v}-6 \mathrm{v}$; J. Rushworth, Historical collections (8 vols., I 72 I), II, pp. 463-9.

${ }^{4}$ Commons Fournals (CF), II, p. 24; The journal of Sir Simonds D'Ewes, ed. W. Notestein (New Haven, I923), pp. I8-I9.
} 
powerful and prolific spokesman for religious toleration and political radicalism. He then became a target for a parliament with whose policies he was disillusioned, and during the republic a sophisticated campaign of literary warfare was waged against him. ${ }^{5}$ However, this article seeks to reinterpret the period during which Lilburne became the villain; the period before the birth of the Levellers. It certainly appears that during this period too Lilburne was 'ungovernable', since he was in and out of prison with alarming regularity. However, there is a danger of succumbing to a retrospective historical analysis and of being hoodwinked by Lilburne's self-publicity. Some scholars misinterpret Lilburne because they treat parliament as a united whole in the midI640s, rather than a body split into rival groups. Thus, when Lilburne is seen to have been imprisoned as a result of a decision at Westminster, he is assumed to have fallen out with 'parliament ${ }^{9}{ }^{6}$ Others err because of an approach which seeks to look for the origins of the Levellers, and thus tends to emphasize only certain elements of his career. ${ }^{7}$ It is entirely legitimate to study Lilburne's radical ideas, and the early phase of the Levellers, since these are undoubtedly important elements of his career. There is, however, a danger of misrepresenting Lilburne if other aspects of his life remain ignored. My aim is not so much to reinterpret Lilburne completely, but to demonstrate a hitherto neglected aspect of his story, and one which suggests him to have been a more complex character than some have been prepared to admit.

I intend to strip away the comments made after Lilburne became a Leveller, and to rescue the narrative of Lilburne's troubles in the mid-i 64 os. $^{8}$ In doing so I shall reassess Lilburne's career by locating him within the factional landscape in the I640s; exploring the ways in which he was both helped and hindered, and by whom. The aim will be to show that Lilburne was neither 'ungovernable' nor perpetually in struggle with his superiors. Lilburne's persecution was not the work of a united parliament, but of the Presbyterians, one of the competing groups at Westminster, who attacked him because of his association with the political Independents. Furthermore, it will be shown that Lilburne formed an integral part of the 'Independent alliance', and that it was this group which protected him. Having established when, why, and by whom Lilburne was befriended, it will then be possible to understand when and why Lilburne and his friends came to blows. The result will be an interpretation which, while not necessarily downplaying the importance of Lilburne as a radical political thinker, seeks to stress that such radicalism did not automatically impact on his political associations. While Lilburne clearly became more radical during the I64os, the crucial development in his political theory will be found not to correlate with the developments in his career. That this is

\footnotetext{
${ }^{5}$ J. T. Peacey, 'Henry Parker and parliamentary propaganda in the English Civil Wars' (Ph.D. thesis, Cambridge, I994), pp. 2 I $7-24 . \quad{ }^{6}$ Gregg, Free-born Fohn, pp. I 2 I, I $26-7$.

${ }^{7}$ J. Frank, The Levellers (New York, I969), pp. 45-108; F. D. Dow, Radicalism in the English Revolution, I640-I660 (Oxford, I985), p. 35.

${ }^{8} \mathrm{~J}$. Lilburne, The legal fundamental liberties (2nd edn, I649).
} 
the case has to do with the nature of the political alliance of which Lilburne formed a part, and detailed scrutiny of Lilburne's career in the mid-r640s suggests that it was his relationship with the complex and shifting factions and their personalities which is crucial for an understanding of the vicissitudes of his career.

I

Until the spring of $\mathrm{r} 645$ Lilburne was a faithful servant of parliament. During I64I, while parliament considered his treatment during the 'personal rule', Lilburne was active in mobilizing mass demonstrations, ${ }^{9}$ and upon the outbreak of war established a military reputation under Lord Brooke. ${ }^{10}$ When Lilburne was captured by royalists and threatened with execution, parliament threatened retaliation, ${ }^{11}$ ensuring that Lilburne was reprieved and made the beneficiary of a high-level prisoner exchange. ${ }^{12}$ Highly regarded by parliament, he was recruited into military service in the regiment of Colonel Edward King, rising to the rank of lieutenant colonel under the earl of Manchester. ${ }^{13}$ Conventional wisdom, however, suggests that Lilburne broke with parliament in early i 645 . One scholar has claimed that this period marked 'a genuine turning point in the history of the revolution', that it was the point at which 'the iron appears to have entered Lilburne's soul', and that it marked 'the genesis of the Leveller party as a self conscious entity'. ${ }^{14}$ Although recent scholarship has begun to undermine the idea of tracing the emergence of the Levellers back to $1645,{ }^{15}$ too many scholars have emphasized Lilburne's conflicts with parliament, and his contacts with radicals, while ignoring the elements of co-operation. ${ }^{16} \mathrm{He}$ certainly began to frequent London's prisons, and made the crucial conceptual developments in his political thought, by suggesting that parliament was susceptible to criticisms formerly levelled at the

\footnotetext{
${ }^{9}$ British Library (BL), Harleian MS I63, fos. I28, I97; Cf, II, p. I34; B. Manning, The English people and the English Revolution (London, I991), pp. 63-4; K. Lindley, Popular politics and religion in Civil War London (Aldershot, I997), pp. 22, 31, I Io; Lords fournals (Lf), iv, p. 233.

${ }_{10}$ PRO, SP $28 / 3$, fo. 2 I 9.

${ }^{11}$ Englands weeping spectacle (1648), pp. 4-5; CF, II, p. 892; Rushworth, Collections, v, p. 93; J. Lilburne, A letter sent from Captain Lilburne ( I643); LF, II, p. 497; House of Lords Records Office (HLRO), MP I7/I2/42; Speciall Passages, 18 (6-13 Dec. I642); The examination and confession of Captaine Lilbourne (1642), A true and most sad relation of the hard usage and extrem cruelty ( 1642 ).

${ }^{12}$ CF, III, p. 84. $\quad{ }^{13}$ The Kingdomes Weekly Post 4 (22-8 Nov. I643), p. 3 o.

14 J. R. MacCormack, Revolutionary politics in the Long Parliament (Cambridge, MA, 1973), pp. $90-\mathrm{I}$.

${ }_{15}$ P. R. S. Baker, 'The origins and early history of the Levellers, c. $1636-$ c. I647' (Ph.D. thesis, Cambridge, forthcoming). I am exceedingly grateful to Phil Baker for making some of his research available to me.

${ }^{16}$ M. A. Gibb, Fohn Lilburne the Leveller (London, I947), pp. I24-9; T. G. Pease, The Leveller movement (Gloucester, MA, I965), pp. 95-I 19; Tolmie, Triumph of the saints, pp. 49, I44-9; M. Kishlansky, The rise of the New Model Army (Cambridge, I 979), pp. 89, I 22, I 33; H. N. Brailsford, The Levellers and the English Revolution (London, I976), pp. 90-5; The writings of William Walwyn, ed. J. R. McMichael and B. Taft (London, I 989), pp. 2 I-6; Gregg, Free-born Fohn, pp. I 2 I-3, I 27 ; G. E. Aylmer, The Levellers in the English Revolution (New York, 1975), pp. I6-I 7.
} 
king, and that parliamentarian theory could justify resistance to parliament. ${ }^{17}$ It is clearly tempting, therefore, to assume that Lilburne's troubles were caused by his emergent radicalism. It would be wrong to make such a connection, however, since to do so would fly in the face of the detailed evidence regarding Lilburne's 'troubles', and fall into the trap of reading back into the mid-I 640 s comments which both Lilburne and his enemies made subsequently. Lilburne's numerous comments upon his trials and tribulations are as problematic as they are valuable, and must be supplemented with evidence from other sources, both official and unofficial.

Lilburne began to face problems in I645, but Gerald Aylmer is correct to suggest that this period marked only 'the beginning of Lilburne's breach with the Long Parliament ${ }^{\prime}{ }^{18}$ His tribulations began because he had aligned himself with the 'Independents', both political and religious, rather than because he had developed a radical ideology. His problems were caused by Presbyterians, and not by parliament as a whole. Lilburne's difficulties stemmed from his relationship with Colonel King, whose aggressive Presbyterianism made him a controversial figure. In the aftermath of Marston Moor, the controversy surrounding King became more serious, and Lilburne teamed up with the county committee in Lincolnshire in the hope of getting King courtmartialled. ${ }^{19}$ In November I 644, furthermore, Lilburne was one of Cromwell's allies in the dispute with the earl of Manchester, and was thus involved in creating the impetus to 'new model' the army. ${ }^{20}$ Furthermore, Lilburne began to develop his attack upon Presbyterianism. One prominent Presbyterian, John Bastwick, claimed that Lilburne's religious radicalism developed during the i63os, but such comments must be treated sceptically, since they were not made until late $\mathrm{i} 645$, after he had joined the campaign against Lilburne. What Bastwick omitted to say was that the two men had remained friends, and that Lilburne had greeted him on his release from a royalist prison in October I $644 .{ }^{21}$ It was only at the end of 1644 that Lilburne became a warrior for the Independent cause, after becoming disillusioned with two of Manchester's Presbyterian divines, Simeon Ashe and William Goode. ${ }^{22}$ Lilburne began to develop his attack upon Presbyterianism in early I645, alongside controversialists such as John Goodwin, and with the assistance of Marchamont Nedham, the leading parliamentarian journalist, who was well connected to the Independent grandees. ${ }^{23}$

${ }^{17}$ A. Sharp, 'John Lilburne and the Long Parliament's Book of declarations: a radical's exploitation of the words of authorities', History of Political Thought, 9 (1988), pp. 19-44.

${ }_{18}$ Aylmer, The Levellers, p. I8.

${ }^{19}$ C. Holmes, 'Colonel King and Lincolnshire politics, I642-I646', Historical Fournal, I6 ( 1 973), 455-7 I ; J. Lilburne, The just man's justification (2nd edn, I647), pp. 2-3, 22-4.

${ }^{20}$ Calendar of state papers domestic (CSPD) I644-5, pp. I 48-9; J. Lilburne, Innocency and truth ( 1645$)$, p. 22 ; J. Lilburne, The prisoners mournfull cry (I648), p. 8.

${ }^{21} \mathrm{~J}$. Bastwick, A just defence (I645), pp. I4-15; M. J. Condick, 'The life and works of John Bastwick, I 595-I654' (Ph.D. thesis, London, I983), pp. 9I-4, I47-8, I 55-6.

${ }^{22} \mathrm{~J}$. Lilburne, The grand plea of Lieut. Col. Fohn Lilburne (1647), pp. 2-3; Lilburne, Innocency and truth, p. 24 .

${ }^{23} \mathrm{~J}$. Lilburne, An answer to nine arguments (I645); Peacey, 'Henry Parker', p. I 58. 
Lilburne's alliance with Cromwell certainly made him enemies, but his attack upon Presbyterianism and Colonel King, and his association with Marchamont Nedham, aroused the ire of two men in particular, William Prynne and John Bastwick. It was this clash - part theology, part ideology, and part personality - which provides the key to understanding Lilburne's career in the mid-I640s. Prynne, the dogged champion of religious Presbyterianism, engaged in interminable pamphlet controversies over church government, and to some extent Lilburne was simply a participant in this debate. ${ }^{24}$ Having joined the Independent alliance, however, Lilburne offended Prynne further by attacking his close friend, Colonel King, ${ }^{25}$ and by working with his bitter enemy, Marchamont Nedham. ${ }^{26}$ These ingredients combined to produce a potent brew in January i 645 . When Lilburne replied to a work by Prynne called Truth triumphing - with an open letter in which he complained of Presbyterian constraints on liberty of conscience and freedom of the press - he found himself in trouble with parliament's committee of examinations. ${ }^{27}$ The serious injury which Lilburne subsequently received caused the planned trial to be suspended, but did not prevent him from travelling to Lincolnshire and resuming his attack upon Colonel King. Upon his return to London in May, however, Lilburne was called before the committee of examinations ( 16 May), ${ }^{28}$ and when he published the answer to his interrogators (I 7 May) was ordered to be arrested (I 8 June). ${ }^{29}$ The danger inherent in relying upon Lilburne's account of this episode is overcome by the fact that Prynne concurred in apportioning responsibility for these events. Both men recorded the confrontation which occurred between Lilburne and Prynne in Westminster Hall, and both agreed that it was Prynne who ensured that the matter was brought to the attention of the committee of examinations. Furthermore, both accounts confirm that Prynne was present at the hearing, ${ }^{30}$ where Lilburne claimed to have been 'tossed and tumbled' by his adversary, 'so as if he would have beat me to dust and powder' ${ }^{31}$ It seems clear, therefore, that it was Prynne who persecuted Lilburne in June I645, and that his animus was

\footnotetext{
${ }^{24} \mathrm{~J}$. Goodwin, Innocency and truth triumphing (I645); Fohn Vicars to Fohn Goodwin (I645); $\mathrm{J}$. Goodwin, Calumny arraigned and cast ( $\mathrm{I} 645) ; \mathrm{J}$. Vicars, To his reverend and much respected good friend $\mathrm{Mr}$ Fohn Goodwin (1645); W. Walwyn, A helpe to the right understanding ( I645); W. Prynne, A fresh discovery of some prodigious new wandring-blasing-stars ( 1645$), \mathrm{pp} .3,34,38 ; \mathrm{J}$. Vicars, The picture of Independency ( 645 ), pp. 8-9; M. N[edham], Independencie no schisme (i646).

${ }^{25}$ Lf, vi, pp. 573-6; Holmes, 'Colonel King', pp. 460, 473; J. T. Peacey, 'Politics, accounts, and propaganda in the Long Parliament', in Chris R. Kyle and J. T. Peacey, eds., Parliament at work, I5IO-I670 (forthcoming). $\quad{ }^{26}$ Peacey, 'Henry Parker', pp. I 54-5, I 79-80.

27 J. Lilburne, A copie of a letter ... to Mr William Prinne (i645); Perfect Diurnall, 77 ( I3-20 Jan. I645), p. 6iг; W. Prynne, The lyar confounded (1645), pp. $3-4 ; L \mathcal{F}$, viI, p. I42; Historical Manuscripts Commission (HMC), Sixth report (Nendeln, 1979), p. 46; H. R. Plomer, 'Secret printing during the Civil War', The Library, n.s., 5 (I904), pp. 374-403.

${ }^{28}$ Prynne, Lyar, pp. 4-5; Lilburne, Innocency and truth, p. 9.

${ }^{29}$ Prynne, Lyar, p. 6; J. Lilburne, The reasons of Lieu. Col. Lilbournes sending his letter (1645); Lilburne, Innocency and truth, p. Io.

${ }^{30}$ Prynne, Lyar, pp. 4-5; Lilburne, Innocency and truth, pp. 9-10; Prynne, Fresh discovery, p. 34.

${ }^{31} \mathrm{~J}$. Lilburne, The resolved mans resolution (I647), p. 30.
} 
based upon personal and religious differences, as well as his desire to protect Colonel King.

There was a wider context to this battle between Lilburne and Prynne, however, which involved the bigger picture of Westminster politics. Prynne probably sought to serve the interests of his friends among the parliamentary Presbyterians, to whom Lilburne posed a growing threat. In April i645, Lilburne had informed Cromwell and Sir Henry Vane about the behaviour of Denzil Holles, one of their Presbyterian political rivals, who had allegedly been involved in negotiations with royalists in I643. Prynne probably sought, in other words, to prevent Lilburne giving evidence during the 'Savile affair', a complex political scandal during June and July, in which the Independents made such reports public. Once Lord Savile had made his accusations regarding the treachery of the leading Presbyterians, the matter was subject to detailed scrutiny, and those, like Lilburne, with a story to tell, were likely to be given the chance to make their own evidence public. ${ }^{32}$ It is this wider context which goes some way to explaining why Lilburne was being protected by elements within Westminster who wanted to discredit Holles, and who ensured that Lilburne was released in June I645 without charge. The contribution which Lilburne was able to make to the Savile affair, therefore, may explain both the Presbyterian attempt to silence him and the Independent desire to protect him. Lilburne's release clearly annoyed Prynne, who accused the committee of examinations of being too 'indulgent' towards him, and the political sympathies of the committee's chairman, Miles Corbet, certainly lay with the Independent alliance. ${ }^{33}$ In later years, Lilburne claimed that 'black Corbet' had worked against him, but it seems likely that, on the contrary, he worked to achieve the opposite outcome. ${ }^{34}$

That this wider context of parliamentarian factionalism is crucial to Lilburne's story becomes clear from events in July i 645 . Within weeks of his release, Lilburne again provided grounds for his opponents to order his arrest, having been overheard in the Court of Requests making allegations regarding the speaker, William Lenthall, and the prominent Presbyterian grandee, Sir Robert Harley (I $\mathrm{July}$ ). ${ }^{35}$ Lilburne later blamed Lenthall for his arrest, but the contemporary evidence suggests that it was the Presbyterian friends of William Prynne who masterminded the prosecution. ${ }^{36}$ It was certainly a Presbyterian newspaper which claimed that Lilburne was arrested 'for reporting some false and scandalous words concerning a worthy member of the

\footnotetext{
${ }^{32}$ HLRO, MP $30 / 6 / 45$, fos. 26o, 262v-3; MacCormack, Revolutionary politics, p. 86; BL, Add. MS I8780, fo. 79b; M. Mahony, 'The Savile affair and the politics of the Long Parliament', Parliamentary History, 7 ( I 988), pp. 2 I 2-27; P. Crawford, Denzil Holles (London, I 979), pp. 99-1 22; V. Pearl, 'London puritans and Scotch fifth columnists: a mid-seventeenth-century phenomenon', in A. Hollaender and W. Kellaway, eds., Studies in London history (London, I 969), pp. $3^{\mathrm{I}}$ 7 $^{-} \mathrm{3}^{\mathrm{I}}$.

${ }^{33}$ Prynne, Lyar, p. 6; W. Epstein, 'The committee for examinations and parliamentary justice, I642-I647', Fournal of Legal History, 7 ( I986), pp. 3-22.

${ }^{34}$ Lilburne, Legal fundamental liberties (2nd edn), p. 28.

${ }^{35} C \mathcal{F}, \mathrm{IV}$, p. 2 I 3.
}

${ }^{36}$ Lilburne, Legal fundamental liberties (2nd edn), p. 28. 
honourable House of Commons, whose integrity and fidelity is well known, and upon whom no blemish could as yet fasten' ${ }^{37}$ Furthermore, Lilburne's loose words were reported to the Commons by Colonel King and John Bastwick, who had recently ventured into print as an ally of the Presbyterians. It was they who ensured that Lilburne was taken into custody and held until his appearance before the committee of examinations on $24 \mathrm{July} .{ }^{38}$ They were not simply satisfying their own malice, however, but serving the interests of the Presbyterian faction. This is clear from the fact that Lilburne was arrested on the day following the Commons's summons for him to give evidence in the Savile affair. ${ }^{39}$ Lilburne was probably arrested, in other words, for things that he might have been about to say, rather than for what he had said already.

Lilburne, however, was already addicted to producing self-justificatory pamphlets, and promptly published his version of the events surrounding his arrest, doubtless to the delight of his enemies. Lilburne's egocentric and reckless behaviour made further action inevitable, and a report by John Glyn (9 August), paved the way for Lilburne's committal to Newgate, pending a new trial. ${ }^{40}$ That the prosecution was to be marshalled by Glyn suggests the influence of the Presbyterians once again, and Lilburne certainly considered him to be his 'professed enemy'. ${ }^{41}$ Indeed, Lilburne detected a Presbyterian conspiracy against him, and while in custody in August I 645 he alleged that Bastwick, Prynne, and King had been set to work 'to make an uproar in the city', where Lilburne's friends were framing an important petition (presented on 26 August). Scared of his influence, Lilburne alleged, these men proceeded by 'framing, posting, and dispersing scandalous paper libels ... to make me odious and destroy me'. ${ }^{42}$ Lilburne had good grounds for suspecting a plot, since the efforts of this cabal resulted in a pamphlet which clearly sought to attack him. ${ }^{43}$

Lilburne had, it seems, become a pawn in the political struggles within Westminster, and once more a change in his fortunes was effected only by friends among the political Independents. On i3 August, new men were enlisted to be involved in the trial, in a fairly transparent attempt to protect him. John Bradshaw, the future president of the Rump's council of state, was ordered to take the examination of Lilburne, and 'to manage such proofs as shall appear'. ${ }^{44}$ Bradshaw's assistant on this occasion was a Lincoln's Inn

37 Mercurius Civicus, i I 3 ( I 7-24 July i645), p. I оо I.

${ }^{38}$ Prynne, Lyar, pp. 6-7; J. Lilburne, The copy of a letter from Lieutenant Colonell Fohn Lilburne to a friend (г645), pp. I, 8, 9, I 2 ; Lilburne, Innocency and truth, pp. го, г 3; J. Lilburne, England's miserie and remedie ( I 645), p. 3; Lilburne, Grand plea, p. 3 ; Condick, 'John Bastwick', pp. I 56-6 I ; Bastwick, Just defence, pp. 7-8; Lilburne, Just mans justification (2nd edn), p. 3; C. J, Iv, p. 2 I 5 .

${ }^{39}$ Cf, iv, p. 2 I 2 ; BL, Add. MS i8780, fo. 79 b.

40 Lilburne, Copy of a letter ... to a friend; CF, Iv, pp. 235, 236-7; BL, Add. MS i878o, fo. 93a; BL, Add. MS 3 I I 6 , p. 450; Lilburne, Innocency and truth, pp. I 5 , I 7.

41 Lilburne, Fust mans justification (2nd edn), p. 25; Prynne, Lyar, pp. 7-8; D. Underdown, Pride's purge (Oxford, I97 I), pp. 69, 8I .

42 J. Lilburne, England's birthright justified ( 1645 ), p. 26 ; Lilburne, Innocency and truth, pp. $28-9$.

43 Bastwick, Fust defence, pp. 4, 8. $\quad{ }^{44}$ CF, Iv, p. 239; BL, Add. MS I878o, fo. 95b. 
lawyer named Gabriel Becke, who was a client of Viscount Saye, and widely regarded as his political puppet. ${ }^{45}$ Lilburne would later allege that Bradshaw's appointment represented an attempt to convict, rather than assist, him, but his retrospective interpretation conflicts with the action of those most anxious to secure a successful prosecution. ${ }^{46}$ The Presbyterians, probably alarmed by the appointment of Bradshaw and Becke, and suspicious that they would obstruct a successful prosecution, ensured that they were quickly discharged (26 August). They were replaced by two less controversial figures, Walter Walker and William Steele, who were probably regarded as being more reliable, or more pliable. ${ }^{47}$ Nevertheless, such political manoeuvring failed to ensure that the prosecution's case was produced at the quarter sessions (89 October), and after issuing both an appeal to the lord mayor, and more selfjustificatory pamphlets, Lilburne was released ( 14 October) ${ }^{48}$ In response to what they probably regarded as a shambolic and disappointing affair, however, the Presbyterians were determined to salvage some political advantage. First, a warrant was issued to search for copies of one of Lilburne's books, England's birthright, which was derided as 'a scurrilous and scandalous libel'. ${ }^{49}$ More importantly, revenge was exacted with the appearance of Prynne's stinging attack upon Lilburne in The lyar confounded, which appeared on the very day that he was set free. ${ }^{50}$ The appearance of this work reinforced Lilburne's opinion that Prynne had had 'more than a finger' in his initial arrest, and he commented that when Prynne saw 'that I was likely honourably to be delivered as a spotless and innocent man, he frames a book, and publishes it cum privilegio ${ }^{51}$

During I 645 , therefore, Lilburne was targeted by the Presbyterians, who attacked him not just on account of his alignment against Prynne, Colonel King, and the earl of Manchester, but because of the threat he posed to Holles and the Presbyterian grandees. They did not attack him, however, on the basis of his political theory, which was largely ignored at this stage. More complex is Lilburne's relationship with the Independents, who were clearly protecting him. Lilburne's radicalism did not stand in the way of his close alliance with the Independents because of the very nature of the 'Independent alliance' at this point. In the early months of the Civil War, parliamentarians have generally been described as having formed three loose groups: the 'war', 'peace', and 'middle' groups. ${ }^{52}$ During late i 644 and I645, however, a realignment took

\footnotetext{
${ }^{45}$ CF, III, p. 653; CF, iv, pp. I 55, I69; HMC, Sixth report, p. 63; J. T. Peacey, 'Led by the hand: manucaptors and patronage at Lincoln's Inn in the seventeenth century', fournal of Legal History, I8 ( I997), pp. 26-44. $\quad{ }^{46}$ Lilburne, Legal fundamental liberties (2nd edn), p. 28.

${ }_{47}$ C.J., Iv, p. 253; Lilburne, Innocency and truth, p. 30.

${ }^{48}$ Lilburne, Innocency and truth, pp. 30, 33, 34, 38; J. Lilburne, England's lamentable slaverie ( I645); Lilburne, Englands birthright justified; CF, Iv, p. 307.

49 The True Informer, 27 (25 Oct. I645), p. 2 I I.

${ }^{50}$ CF, iv, p. 307; Prynne, Lyar, sig. A3. ${ }^{51}$ Lilburne, Resolved man's resolution, p. 30.

${ }^{52}$ J. H. Hexter, The reign of King Pym (Cambridge, MA, I96I); V. Pearl, 'Oliver St John and the middle group in the Long Parliament', English Historical Review, 8I (I966), pp. 490-519; Underdown, Pride's purge, pp. 45-65.
} 
place, during which the 'middle' group and the 'war' party joined forces to form the 'Independent alliance'. While members of this group differed over ultimate aims, they worked together in the interests of the war effort, in order to be able to secure a settlement from a position of strength. ${ }^{53}$ They, like the Presbyterians, were by no means sufficiently organized to be called a political 'party'. Nevertheless, the working coherence of both groups, and the extent of the divisions between them, was significant, and has been underestimated by some historians. ${ }^{54}$

It was this Independent alliance which protected Lilburne, even if different elements valued him for different reasons. The 'Royal Independents' - the members of Hexter's 'middle group' - did not share Lilburne's radical ideas, but were prepared to exploit him as a weapon against the Presbyterians, particularly during the Savile affair. ${ }^{55}$ Furthermore, they probably valued him as a man with influence amongst the sectarian churches in London, and if Nalson was correct in suspecting that political grandees were prepared to sanction the use of mass demonstrations as a political tool, then Lilburne may have been indispensable. ${ }^{56}$ An indication of Lilburne's cosy relationship with the 'Royal Independents' in I 645 lies in his comments regarding the grandees at Westminster. In later years Lilburne would be scathing about the Independents, but in 1645 he offered little but praise. In the wake of his spell in prison in the autumn of $\mathrm{I} 645$, Lilburne certainly showed signs of doubting Sir Henry Vane, Oliver St John, and Oliver Cromwell, but his letter to Cromwell of December i 645 was full of warmth, and replete with expressions of friendship. ${ }^{57}$

While the 'Royal Independents' were prepared to tolerate Lilburne, other members of the Independent alliance shared his ideas, particularly protorepublicans such as Henry Marten. ${ }^{58}$ This is clear from one particular pamphlet which appeared in the wake of both Lilburne's release and Prynne's attack in the autumn of i645. This was the Tractatus by a Lincoln's Inn lawyer called William Ball, ${ }^{59}$ a friend of Henry Marten who was attempting to secure a parliamentary seat with his help. ${ }^{60}$ In many ways Ball's pamphlet outlined a conventional contractualist parliamentarian theory, but the novelty lay in his

\footnotetext{
${ }^{53}$ Underdown, Pride's purge, pp. 7 I-2. $\quad{ }^{54}$ Kishlansky, New Model Army, pp. 21 2-27.

55 V. Pearl, 'The 'Royal Independents' in the English Civil War', Transactions of the Royal Historical Society, 5th ser., I8 (1968), pp. 69-96.

${ }^{56}$ Nalson, Impartial collection, I, p. 57 o. I am grateful to Phil Baker for a discussion on this point.

57 Lilburne, England's birthright justified, pp. 30, 33; J. Lilburne, Fonahs cry (1647), pp. I2-13.

${ }^{58}$ C. M. Williams, 'The anatomy of a radical gentleman: Henry Marten', in D. Pennington and K. Thomas, eds., Puritans and revolutionaries (Oxford, I978), pp. I 18-38.

${ }_{59} \mathrm{~W}$. Ball, Tractatus de jure regnandi ( 1645$)$.

${ }^{60}$ The four visitations of Berkshire, ed. W. H. Rylands (2 vols., London, I 908), II, p. 62; Reading records, ed. J. M. Guilding (4 vols., London, I 896), Iv, pp. I67-8, I 70-5; C F, Iv, p. 346; Berkshire Record Office, TF 4I (Abingdon corporation minute book I 59 I-I686), fos. I69r-v; CF, Iv, p. 397. This material stems from research into Ball's career which I have undertaken for the History of Parliament.
} 
refusal to admit that parliament's power was 'unlimited or boundless'. The English constitution was a mixture of monarchy, aristocracy, and democracy, but one in which democracy prevailed, and in which rights existed against parliament as well as the king. If parliament, the people's representative body, could raise arms for the defence of the kingdom, so too could the people. They were the 'essential' body of the kingdom, and did not 'disinvest themselves of their right natural' by 'reposing or granting such trust' in parliament. ${ }^{61}$ The Lilburnian traces in this position are clear, and reveal that, far from alienating friends with his radicalism, Lilburne found himself in agreement with powerful voices at Westminster. Just as Lilburne had been protected from the Presbyterians in I645, so theorists such as Ball may have been spurred towards publication by the need to bolster Lilburne in his hour of need. Indeed, the appearance of Ball's tract was the first evidence of a more coherent and subtle campaign in support of Lilburne, whereby a public relations exercise was undertaken to raise his profile, and to defend him against the Presbyterians.

\section{I}

Having established the narrative of Lilburne's career during i645, and the nature of his relationship with the political scene at Westminster, it is now necessary to assess how such relationships fared in the ensuing months, and how the changing balance of power between competing groups affected Lilburne. Not surprisingly, the attitude of the Presbyterians changed little. A distinct group in parliament ensured that Lilburne faced renewed difficulties almost immediately after his release in October i645. On io November, Lilburne presented a petition regarding the discharge of his Star Chamber fine, which had been hanging over him since I $637{ }^{62}$ Rather than help him, however, the Commons referred Lilburne's affairs to the committee of accounts, which was emerging as a powerful tool of the Presbyterian faction, under the chairmanship of Lilburne's enemy, William Prynne. ${ }^{63}$ Lilburne clearly saw this as another attempt to harass him, particularly since the committee was ordered to take evidence from another enemy, Colonel King. ${ }^{64}$ Lilburne's friends, however, stepped in to protect him from Prynne once again, and on I 3 February I646, the Lords heard the case of his Star Chamber fine by the counsel that he himself had requested, John Bradshaw and John Cook. ${ }^{65}$ The Lords ratified the Commons decision to discharge the fine, and the process of granting reparations was supported by the two most powerful Independent grandees, Viscount Saye

61 Ball, Tractatus, sig. A2, pp. 2-5, 7, 9-10, I 2-13, I 5.

${ }^{63}$ CF, Iv, p. 338; Peacey, 'Politics, accounts and propaganda'.

${ }^{62} C \mathcal{F}, \mathrm{sv}, \mathrm{p} .33^{8}$.

${ }^{64} C \mathcal{F}$, Iv, p. 338; Lilburne, Innocency and truth, pp. 64-5, 68-72.

65 Lilburne, fust mans justification (2nd edn), p. 26; Lf, viII, pp. I 27, I64-5; HLRO, MP 2/2/46; A Diary, or an Exact Fournall, 4 ( I 2-I 8 Feb. I646), p. $2 ;$ A true relation of the materiall passages of Lieut. Col. John Lilburnes sufferings (г646); T. Barnard, Cromwellian Ireland (Oxford, I975), pp. 262-76; J. S. A. Adamson, 'The English nobility and the projected settlement of i647', Historical Fournal,

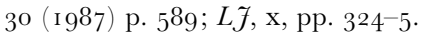


and Lord Wharton. ${ }^{66}$ Such political action in defence of Lilburne coincided with further favourable comments regarding him in the press, particularly in Mercurius Britanicus, which was written by Lilburne's old friend Marchamont Nedham, and which had become a powerful mouthpiece for the Independents. ${ }^{67}$ Lilburne's success in avoiding action by the committee of accounts, and in garnering support in parliament and the press, reflected the down-turn in the fortunes of the Presbyterian faction. Correspondingly, the revival of the earl of Essex and the high Presbyterians as a political force, during the later spring and early summer of 1646 , posed new problems for Lilburne, particularly when Nedham was silenced ${ }^{68}$ As a result of such changes, the Presbyterians were able to ensure that Lilburne's press was tracked down and seized, ${ }^{69}$ and by April I 646, Lilburne faced charges of having slandered his old foe Colonel King, and was returned to prison. Lilburne again blamed Prynne for instigating the moves against him. ${ }^{70}$

It has been claimed that 'Lilburne looked in vain to Cromwell and the radicals for support' in the spring of I 646 , that he was 'completely disillusioned with the parliamentary radicals', and that his opposition by this stage was 'implacable'. ${ }^{71}$ Lilburne certainly claimed later that he had been 'left in the suds by L[ord] G[eneral] Cromwell' ${ }^{72}$ Nevertheless, Lilburne's subsequent resentment against his old friends in parliament should not cloud our judgements, and once again the facts do not support the thesis that Lilburne was without friends in I 646 . In fact, Lilburne was released fairly rapidly, and was involved, in late May 1646 , in the distribution of a pamphlet at Westminster called $A$ word in season. ${ }^{73}$ This work was an attack upon Presbyterian propaganda from the City, and the petition then being circulated which called for negotiations with the king. ${ }^{74}$ The London petition was an ominous sign of the balance of power in the capital, and the Independents clearly wanted to counter its influence. It seems likely that Lilburne was enlisted to support the Independents, alongside other trusted allies of the faction at Westminster. This particular pamphlet, which was licensed by one of the Independents' close friends, John Bachelor, was probably a collaborative

${ }^{66}$ CF, Iv, p. 338; A true relation of the materiall passages, p. I ; LF, viII, pp. I94, 21 7, 272; Perfect Passages of Each Dayes Proceedings, 7I (25 Feb.-4 Mar. I646), pp. 564-5; The Weekly Account, 9 ( $18-24$ Feb. I646), sigs. I 3 v-I4; Perfect Occurrences, 7 I (г 3 Mar. I646), sig. L.

${ }_{67}$ Mercurius Britanicus, I I6 (26 Jan.-2 Feb. I646), p. I02 I ; J. S. A. Adamson, 'The peerage in politics, I645-I649' (Ph.D. thesis, Cambridge, I 986), p. I 59; Peacey, 'Henry Parker', pp. I 54-9; Mercurius Britanicus, I2 I (9-16 Mar. I646), p. I058; Mercurius Britanicus, I 27 (20-7 Apr. I646), pp. Io88-9, го94.

${ }_{68}$ Peacey, 'Henry Parker', pp. I58-9; Adamson, 'Peerage in politics', pp. I30-68.

${ }^{69}$ The petition and information of Joseph Hunscott $(\mathrm{I} 645) ;$ A true relation of all the passages ... against William Larnar ( 1646); Plomer, 'Secret printing', pp. 389-403.

${ }^{70}$ Lilburne, Resolved mans resolution, p. 39; Lilburne, Grand plea, p. 3.

${ }^{71}$ MacCormack, Revolutionary politics, pp. 91, I29.

${ }^{72}$ Lilburne, Fust man's justification (2nd edn), p. 26.

${ }^{73} \mathrm{~J}$. Sadler, $A$ word in season (1646, BL, E $1184 / 3$ ).

74 M. Mahony, 'Presbyterianism in the City of London, I645-1647', Historical Fournal, 22 (I979), pp. 93-I I4; Adamson, 'Peerage in politics', pp. I33-4. 
effort by two well-known pamphleteers, John Sadler and William Walwyn. ${ }^{75}$ It is possible that Lilburne was on friendly terms with both men, since Walwyn was another future Leveller, while Sadler was, like Lilburne, a former colleague of Lord Brooke. The possibility that this pamphlet received tacit support from the Independent grandees is enhanced by the fact that Sadler was a special secretary to parliament, having been employed in I 645 to publish the king's 'Naseby letters'. ${ }^{76}$

Although the Independents protected Lilburne in the spring of 1646 , his work against the Presbyterians, and his renewed attack upon Colonel King and the earl of Manchester, ensured that his tribulations continued. On io June I 646 a new warrant was issued for Lilburne's arrest, probably on Manchester's orders. ${ }^{77}$ Once more, it has been claimed that Lilburne was committed to prison 'with no perceptible protest from his old friends', but again the evidence is more ambiguous. ${ }^{78}$ On his way to appear before the Lords (I I June), Lilburne 'took sanctuary at a friend's lodging' in order to compile a protestation to deliver to parliament. Having drafted his piece, Lilburne then visited the Independent grandee, Lord Wharton, to show him the work, and to enjoin him to use it to lobby the peers. ${ }^{79}$ Wharton was, as contemporaries recognized, Lilburne's greatest ally in the Lords, and must have been expected to offer assistance ${ }^{80}$ Nevertheless, Lilburne's efforts to rally the Independent aristocracy appear to have proved fruitless. He received little by way of constructive help in parliament, and was committed to Newgate following the hearing. ${ }^{81}$

The ambiguity of the evidence surrounding these events centres on the problems of interpreting the lack of 'perceptible protest' from Lilburne's allies. It is less certain that Lilburne's friends had abandoned him than that his enemies were in a position of great strength in the Lords. The Presbyterians certainly appear to have been masterminding a campaign against Lilburne in the upper House. At the hearing, three Presbyterian earls (Manchester, Stamford, and Lincoln) spoke against him, and the committee nominated to investigate his case was predominantly Presbyterian as well. ${ }^{82}$ It was probably the power of Manchester and the Presbyterian peers, therefore, which resulted

75 [J. Sadler], A word in season (1646, BL, E337/25); A transcript of the registers of the worshipful company of stationers (3 vols., London, I9I $3^{-\mathrm{I}} 4$ ), I, p. 230; The writings of William Walwyn, pp. I96-204; Peacey, 'Henry Parker', pp. 32, 24 I-2.

${ }_{76}$ DNB; A. Woolrych, From Commonwealth to Protectorate (Oxford, I982), pp. 203-9; Peacey, 'Led by the hand', pp. 36-7; Lilburne, fonah's cry, p. 5; J. Lilburne, The upright man's vindication (I653), p. 29.

77 Lilburne, Grand plea, p. 4; J. Lilburne, The free-mans freedom vindicated (1646), p. 3; Lilburne, Just mans justification (2nd edn), p. 27; LJ, viII, p. 368.

78 MacCormack, Revolutionary politics, p. I 56.

79 Lilburne, Freemans freedom vindicated, pp. 4-6; J. Lilburne, The juglers discovered ( I647), p. 9.

80 Mercurius Aulicus, 6 (2-9 Mar. I648), sig. F2v.

81 Lilburne, Freemans freedom vindicated, pp. 4, 7; LF, viII, p. 37o; J. Lilburne, An anatomy of the

Lords tyranny (г646), pp. 3-4; S. Sheppard, The famers fam'd (г646), p. 4.

82 LF, viII, p. 370,387 . 
in Lilburne's being committed close prisoner (23 June), pending the composition of new charges. ${ }^{83}$ When the charge was read before the Lords on I J July - accusing him over his comments regarding Manchester, Stamford, and Colonel King - Lilburne refused to respond, and was proceeded against pro confesso. He was sent to the Tower, and his books were ordered to be burnt. ${ }^{84}$ Nevertheless, a number of pamphlets appeared in Lilburne's defence ${ }^{85}$ and the peers were forced to appoint a committee to investigate complaints regarding one piece, called An alarum to the House of Lords. Although it included Northumberland and Wharton, this committee was essentially Presbyterian in character, and was dominated by Essex, Manchester, Lincoln, and Willoughby ${ }^{86}$ In an effort to undermine Lilburne yet further, this committee employed a stationer called Robert Eeles, who evidently showed some zeal in hunting for Lilburne's presses and pamphlets. ${ }^{87}$ Furthermore, Richard Overton claimed to have been harangued by two of the leading Presbyterian peers (Essex and Hunsdon) at the committee hearing after his arrest. ${ }^{88}$ The order, on I 7 September i646, to fine Lilburne $£_{2}, 000$, and the sentence of seven years in the Tower, was a clear signal of the Independents' failure to protect Lilburne from the Presbyterians in the Lords. ${ }^{89}$ Nevertheless, the reasons for this failure are not entirely clear. It is clear that the Independents would have been unable to protect Lilburne in the upper House, since the Presbyterians increasingly held sway. ${ }^{90}$ It is possible, however, that the Independent peers were largely unwilling to defend their former ally, and the only evidence of assistance was the appointment of Gabriel Becke as counsel to assist in his defence. ${ }^{91} \mathrm{It}$ is possible that the Independents, or at least the 'Royal Independents', had lost patience with Lilburne.

The attitude of the Independents may have been conditioned by the attitude of Lilburne, and if the views of the former are unclear, then the reaction of the latter is plain. It is at this moment, in June I646, that a split between Lilburne and some elements of the Independent alliance occurred, and that he began to wield the theoretical weapon forged from parliamentarian theory. Lilburne had warned in I645 that parliament could be held accountable if it betrayed the trust of the people, and his judgement regarding the legitimacy of parliament was clearly epitomized, if perhaps not determined, by the treatment he himself received. By the summer of I 646 , Lilburne felt betrayed, ${ }^{92}$ and while

\footnotetext{
${ }^{83}$ LF, viII, p. 388; J. Lilburne, The just man in bonds (1646), pp. 3-4; Lilburne, Anatomy, p. 5; Sheppard, Famers fam'd, p. 5 .

${ }^{84}$ Lf, viII, pp. 419, 426-7, 429-30, 432-3; The Scotish Dove, I42 (8-15 July i646), p. 725; Lilburne, Anatomy, p. I 2; [M. Nedham?], Vox plebis (1646), pp. 26-30, $32^{-5}$.

${ }^{85}$ A pearle in a dounghill ( 1646$) ; A$ remonstrance of many thousand citizens (I646).

${ }^{86}$ LF, viII, p. 45I; An alarum to the House of Lords ( 1646 ).

${ }^{87} L \mathcal{F}$, viII, pp. 463,$465 ;$ HLRO, MP I $_{3} / 8 / 46$.

${ }^{88}$ R. Overton, $A$ defiance against all tyrants (I646), pp. 8-9, I 3-I4, I6-I8.

${ }^{89}$ Lf, viII, pp. 493-4; Plomer, 'Secret printing', pp. 374-403; J. Lilburne, Rash oaths unwarrantable ( 1647$)$, p. 3 .

${ }^{91}$ LF, viII, p. 39 I.

${ }^{90}$ Adamson, 'Peerage in politics', pp. I30-68.

${ }^{92}$ Gibb, Fohn Lilburne, p. I 43.
} 
it would be wrong to say that his radical theory was formed by his treatment, ${ }^{93}$ personal experience clearly influenced the timing of its application. This is certainly suggested by an analysis of the nature of Lilburne's split with the Independents, since he initially turned on the Lords rather than the Commons. Although Lilburne had developed a theory of popular rather than merely parliamentary sovereignty, he was not yet using his ideas to their full potential. Instead, he limited himself to an attack upon the House of Lords by asserting the superiority of the House of Commons. Lilburne began to attack his old friends in the upper House in a work published in late June $\mathrm{I} 646$, in which he dismissed their order commanding his appearance. As a free man of England, Lilburne protested that he was 'not to be used as a slave or vassal by the Lords' ${ }^{94}$ The events of the summer of 1646 , and the treatment of Lilburne, coincide with the emergence of the Levellers as a distinct group, as expressed by the Remonstrance of many thousand citizens, published on 7 July by Richard Overton and William Walwyn. Nevertheless, they too expressed hostility to the House of Lords, by means of an appeal to the Commons, ${ }^{95}$ and Overton's other pamphlets make it explicit that the target was 'arbitrary usurpations or encroachments' of the House of Lords 'upon the sovereignty of the supreme House of Commons' ${ }^{96}$

Lilburne criticized the peers as an estate, and it seems that he had split with the more moderate Independents, whose grandees were powerful in the upper House. He had not yet split with all of the Independents, and in spite of his attack on the Lords, the campaign to defend him was not abandoned. Rather, it took a different form; becoming centred on the Commons, where he could expect more favourable treatment. This was not simply because the Independents were more powerful in the lower House, nor simply because republicans such as Henry Marten were active political figures. Lilburne's expectations were reasonable because of the working alliance which survived between Marten and the 'Royal Independents', and while Lilburne appears to have split from the latter in the summer of 1646 , Marten's continued support provided hope. Lilburne's reliance upon Henry Marten was apparent from the moment of his imprisonment in the summer of 1646 . Upon his petition from Newgate (i 6 June), the Commons referred his case to a committee chaired by Marten, and Lilburne certainly claimed to have been 'not a little refreshed' by this move, 'thinking that you [Marten], of all the men in the House of Commons, would have been the most sensible of my condition ${ }^{97}$ Nevertheless, the breaking of one link in the chain which joined the members of the Independent alliance produced unbearable tensions, and it became increasingly clear that a situation in which Lilburne was protected by Marten

93 Tolmie, Triumph of the saints, p. 49.

${ }^{94} \mathrm{~J}$. Lilburne, A copy of a letter sent by Lieu. Col. Fohn Lilburne to Mr Wollaston (1646); Lilburne, Just man in bonds, pp. $\mathrm{I}-4$.

${ }_{95}$ Brailsford, Levellers and the English Revolution, pp. 96-7; The writings of William Walwyn, pp. 24, 223-6. $\quad 96$ Overton, A defiance, title page.

97 Lilburne, Fust mans justification (2nd edn), pp. 9-1 I ; Lilburne, Rash oaths unwarrantable, pp. 2-3. 
could not co-exist with a meaningful relationship between Marten and the 'Royal Independents'. The story of the ensuing months was one in which these tensions became apparent, causing Lilburne to grow disillusioned with the Commons as well as with the peers.

Lilburne became reliant not just upon Marten, but upon Marten's ability to rally others in the Commons and the press, where the Independents had begun to circumvent the predominantly Presbyterian licensing system. ${ }^{98}$ That this was the case is suggested by the support which was forthcoming from the most important pro-Lilburne pamphleteer, William Ball. Since publishing his last pamphlet, Ball had taken a seat in the Commons, almost certainly on the basis of Marten's support, ${ }^{99}$ and his sympathy for Lilburne is clear from a letter which he wrote to William Lenthall expressing contempt for the tyranny of parliamentary authority. ${ }^{100}$ In June 1646 , Ball developed his views in a pamphlet which he subtitled 'the rule of the freeborn people', and which strongly echoed Lilburne's views. Ball emphasized the 'intensive power' of the people, claiming that Englishmen had never assented to any form of arbitrary power, least of all the unlimited power of parliament. He stressed that the people could reassert their primitive intensive power when their fundamental liberties and properties were violated, and said that it was 'destructive to the very essence of their freedom not to be able to determine themselves to that which they conceive to be bonum commune'. Parliament, on this account, was regarded as the highest court, but could not go beyond its trust, while the people remained the highest power; the efficient and final cause of political authority. ${ }^{101}$ Ball's work represented a shot across the bows of parliament, and a warning that if the authorities at Westminster proved tyrannous then the people might legitimately reclaim their primitive powers. Ball, like Lilburne, was not yet claiming that such a stage had been reached, but he was offering a timely warning that the treatment of men such as Lilburne could change this situation.

Pamphlets like Ball's provided the most constructive assistance to Lilburne's cause, if not to the man himself. In the Commons, meanwhile, Lilburne's dwindling group of friends persevered with their attempts to help him, and the committee chaired by Marten continued to sit into late I646. In mid-October I646, it was to Marten that Richard Overton directed his appeal from Newgate, which was published in pamphlet form, ${ }^{102}$ and in early November Lilburne attended a committee hearing chaired by Marten, to whom he subsequently presented a written copy of his speech, as well as a detailed account of his conduct before the Lords. Marten may have realized that he could effect little in parliament, and even that the appointment of his

98 Peacey, 'Henry Parker', pp. 24 ${ }^{\mathrm{I}-5 .} \quad{ }^{99}$ C $\mathcal{F}$, rv, pp. 438, 445.

100 Bodleian Library, MS Tanner 6o, fo. 49 I : William Ball to William Lenthall, i Mar. I645.

101 W. Ball, Constitutio liberi populi (г646), pp. 5, 7, I 2, I 5, I 7.

102 R. Overton, An arrow against all tyrants (I647), pp. 3-I6; R. Overton, The commoners complaint ( 1646$)$, pp. I-23. 
committee had been aimed at sweeping Lilburne's case under the carpet. Marten may, therefore, have arranged for Lilburne's deposition to appear in pamphlet form, as An anatomy of the lords tyranny. ${ }^{103}$ He may also have connived in the appearance of another work defending Lilburne, called Vox plebis (ig November), which recounted his troubles over Colonel King and the earl of Manchester. This was probably the work of Marchamont Nedham, Lilburne's old ally, and another of Marten's friends. ${ }^{104}$

In spite of such pamphlet support, Lilburne, having grown disillusioned with the 'Royal Independents' and the House of Lords, began to despair of his supposed friends in the Commons towards the end of the year, as he languished in prison. Lilburne faced a parliament which was for the most part hostile, even in the Commons, and probably realized that his friends were unable to offer assistance. As a result, he came to regard the entire parliament as tyrannous, and thus susceptible to the theory which he had developed in i 645 . In early I647, the tyranny of parliament was probably epitomized for Lilburne in his harassment by Prynne and the committee of accounts. Lilburne railed against Prynne, who he felt sought to 'blast my reputation and credit, and so by consequence destroy me and mine'. Lilburne claimed that Prynne did so in the knowledge that he was 'fast by the heals under a great indignation of the House of Lords', and that 'my business by way of appeal was depending in the House of Commons, and ready for a report'. Prynne's tactic, according to Lilburne, was to make 'a most false groundless and lying report' from the committee of accounts, 'that I was in their debt above $£ 2$,ooo'. Since this accusation was based upon evidence provided by Colonel King, Lilburne regarded the decision as biased and unreliable. ${ }^{105}$ When Lilburne sought to respond in early January $\mathrm{i} 647$, however, his house was searched, his pamphlets were immediately ordered to be seized and burnt, and he was questioned once more. ${ }^{106}$

It was as a result of his sense of disillusionment and betrayal, and his detection of a new tyranny, that Lilburne grew closer to disgruntled royalists, with whom he began to consort in the Tower of London. The first indication of this new alliance appeared in a pamphlet published in November I646, in which Lilburne responded to criticisms by John White, a warder in the Tower. Lilburne regarded White as a flunky - one of the 'old mastive dogs' who had been set upon him by the Lords - and when he forced White to issue a

103 Lilburne, Grand plea, pp. I-2 ; Lilburne, Juglers discovered, p. 2 ; Perfect Occurrences of Both Houses of Parliament, 46 (6-I3 Nov. I646), sigs. Xxv, $\mathrm{Xx} 3$; The Kingdomes Weekly Intelligencer, $\mathrm{I}_{72}$ (27 Oct. -3 Nov. I646), p. 282 ; Lilburne, Anatomy, pp. I-23.

104 [Nedham?], Vox plebis, pp. 23, 26-30, 32-3, 43, 6o-68; B. Worden, 'Wit in a roundhead: the dilemma of Marchamont Nedham', in S. D. Amussen and M. A. Kishlansky, eds., Political culture and cultural politics in early modern England (Manchester, 1995), p. 320; Lilburne, Rash oaths unwarrantable, p. 3; Lilburne, fuglers discovered, p. 6.

${ }^{105}$ Lilburne, Resolved mans resolution, pp. 3 ${ }^{\mathrm{I}-3}$, 37; Lilburne, fust mans justification (2nd edn), p. 6; $\mathrm{PRO}, \mathrm{SP}_{28}$ / 14 , fos. 86-7.

${ }^{106}$ LF, viII, pp. 645, 647; J. Lilburne, Regall tyrannie discovered (1647); Mercurius Diutinus, I I (3-1o Feb. I647), p. 83; The Weekly Account, 6 (3-1o Feb. I647), sig. F4v; London Post, 5 (4-I I Feb. I647), p. 30; Perfect Occurrences of Every Daie Fournall, 6 (5-I2 Feb. I647), p. 45. 
retraction, he was assisted by royalists such as Sir John Strangeways and Sir Lewis Dyve. ${ }^{107}$ Such contacts were not simply the 'horse-play' suggested by Lilburne's biographers, but reflected a shared hostility to the jurisdiction claimed by Westminster, and doubtless accelerated the rate at which Lilburne alienated former friends amongst the Independents. ${ }^{108}$ Furthermore, as Lilburne began to attack parliament with a new vehemence, the arguments which he developed bore a remarkable similarity to those of the prolific pamphleteer David Jenkins, one of the royalist prisoners in the Tower. As a result of his efforts, Jenkins faced a united front provided by both Lilburne's old enemies, such as Prynne, as well as former friends amongst the Independents, such as Oliver St John, John Bradshaw, and Gabriel Becke, ${ }^{109}$ not to mention old allies from the press, such as William Ball ${ }^{110}$ and Henry Parker. ${ }^{111}$ The prosecution of Jenkins provided a hint of the coalition which would soon conspire against Lilburne himself, particularly since, in June i647, the Lords had concluded that Lilburne and Jenkins were the chief fomenters of the distempers in the army and the city. ${ }^{112}$

Not surprisingly, Lilburne was attacking both the Lords and the Commons by this stage. He not only perceived what recent historians have recognized, namely the existence of a bi-cameral Independent faction, ${ }^{113}$ but suspected that his former friends in the Commons were subservient to the interests of the peers. In June I646, the author of $A$ pearle in a dounghill had referred to the Commons as 'creatures' of the Lords, and in July i647, Lilburne claimed that 'King Cromwell and Prince Ireton' were the 'principal instrument that keep me in prison, because I will not comply with their turncoat lordly interest'. ${ }^{114}$ Lilburne also suggested that Cromwell pleaded 'down right for the Lords', and derided his 'hocus pocus dealing'. ${ }^{115}$ In September I647, when Lilburne repeated his claims regarding Cromwell's 'lordly interest', he added that, 'little good may I or the kingdom expect from his counsell or actions, who is now so closely glued in the interest and counsell to those four sons of Machiavelli, who never heartily loved the liberties of the commons of England in their lives, viz. the lord Say, the lord Wharton, young Sir Henry Vane, and solicitor St John'. ${ }^{116}$ Lilburne provides, therefore, evidence for those who detect the predominance of the 'lordly interest' in English politics at this time, even if it is important to recognize that, imbued with a sense of the peers' betrayal of him

${ }^{107} \mathrm{~J}$. White, Fohn White's defence (1646); J. Lilburne, Londons liberty in chains (I646), p. 63 Lilburne, The oppressed mans oppressions ( (1647), p. 8. $\quad{ }^{108}$ Gregg, Free-born Fohn, p. I46.

${ }^{109}$ W. H. Terry, Fudge Fenkins (London, I 929); W. Epstein, 'Judge David Jenkins and the great Civil War', fournal of Legal History, 3 (I982), pp. I87-22 I.

${ }^{110}$ CF, v, p. I67; W. Ball, The power of kings discussed (1649)

111 Peacey, 'Henry Parker', pp. I 22-3, 289. $\quad 112$ Lf, Ix, p. 244.

113 J. S. A. Adamson, 'Oliver Cromwell and the Long Parliament', in J. S. Morrill, ed., Oliver Cromwell and the English Revolution (London, I990), pp. 49-92; Adamson, 'English nobility', pp. 567-602. $\quad{ }^{114}$ Pearle in a dounghill, p. 4; Lilburne, Fuglers discovered, p. 4.

${ }^{115} \mathrm{~J}$. Lilburne, The additional plea (1647), pp. I 7-23; R. Overton, An appeale from the degenerate representative body (I647).

116 J. Lilburne, Two letters writ by Lieut. Col. Fohn Lilburne (1647), pp. 4-5. 
and his cause, he used the term 'lordly interest' as an insult, and one which he was willing to employ in a libellous and indiscriminate manner. Most crucially, however, Lilburne began to despair of his supporters in parliament. Indeed, by June I 647 , he had even begun to doubt the fidelity of his closest ally, Henry Marten, and criticized his 'dilatory and unjust delaying'. ${ }^{117}$ Lilburne alleged that even the radical element of the Independent alliance had betrayed the cause and sold out to the grandees. He claimed that Marten had 'exasperated the spirits of the House of Lords against me and exposed me to their merciless fury and devouring indignation'.118 Lilburne's partnership with the Independents of all hues appeared to have come to an end, and perhaps it is at this point that the Levellers truly emerged as a force hostile to parliament. ${ }^{119}$

I I I

By the middle of $\mathrm{I} 647$, Lilburne was as keen to infiltrate the army as to work with the royalists, and as the leader of the Levellers his radicalism precluded him from receiving the support of all but a small minority of his former friends. Lilburne not only ceased to be useful, but became a serious threat. Nevertheless, the collapse of the Presbyterian 'counter-revolution', and the army's march on London in August I 647, was followed by another twist in Lilburne's story, since there appears to have been an attempted rapprochement between himself and the Independent grandees. This probably reflected a last ditch effort to buy Lilburne back from opposition, where he could be very dangerous. A meeting between Lilburne and Oliver Cromwell was held in the Tower on 5 September, but it soon became clear that relations were beyond repair, and the meeting did not go well. Cromwell reportedly asked Lilburne 'how it came to pass that he had fallen out with his best friends, and was become so great an enemy to the parliament'. Lilburne apparently replied that 'he neither had, nor ever would, fall out with his friends, but he saw with much grief of heart that those who he esteemed his friends had fallen off both from him and their first principles'. ${ }^{120}$ The reason for the failure to heal the rift between Lilburne and the grandees was the fracturing of the Independent alliance, during which Marten made the decisive split with the 'Royal Independents'. Thereafter, the Independent grandees no longer needed to humour Marten's support of Lilburne. ${ }^{121}$ This split also served to bring the latter two - natural allies - closer together, and Marten appears to have convinced Lilburne that he was not a turncoat, and that he had genuinely been seeking to provide help. Marten asserted that he had tried on numerous occasions to deliver his report to the Commons

117 J. Lilburne, A copy of a letter written to Collonell Henry Marten (г647).

118 Lilburne, Rash oaths unwarrantable, pp. 2-3, 4-5.

119 The writings of William Walwyn, p. 27.

120 'The Tower of London letterbook of Sir Lewis Dyve, I646-47', ed. H. G. Tibbutt, Bedfordshire Historical Record Society, 38 (1958), p. 85; Adamson, 'English nobility', pp. 594-5.

${ }^{121}$ Underdown, Pride's purge, p. 85; Claydon House, Verney papers, Reel 8, unfol. Dr William Denton to Sir Ralph Verney, 6 Oct. I647. 
concerning Lilburne's case, ${ }^{122}$ and was probably responsible for securing Lilburne's arrears of army pay. ${ }^{123}$ As a result, Lilburne claimed to have been given 'full satisfaction' for what he regarded as Marten's 'former negligence'. ${ }^{124}$

The prospects of gaining satisfaction from the grandees, however, were poor. The absence of enthusiasm for a policy of détente with Lilburne on their part is clear from the resistance which Marten and his committee continued to encounter in the early autumn. In mid-September 1647 the committee recommended that Lilburne be awarded reparations, ${ }^{125}$ but a move that he should be released was quashed by the Lords. ${ }^{126}$ Meanwhile, parliament sought to place new controls on the press, and to reform the London militia, on which such legislation was based. ${ }^{127}$ This process, which was aimed at the likes of Lilburne, was masterminded by those Independents whom Lilburne had formerly regarded as his allies. Most interesting is the involvement of William Ball, who remained with the remnants of the Independent alliance after the departure of Henry Marten. Ball guided the press ordinance through the Houses, and was given the responsibility for organizing some of the new system's first victims. ${ }^{128}$ Hostility to Lilburne within Westminster was doubtless exacerbated by the way in which, in his deposition to the Commons in the first week of October, he again denied the jurisdiction of the Lords over a commoner like himself. ${ }^{129}$ Through Marten's persistence, the Commons did eventually agree to consider the committee's report ( 15 October), but when Lilburne appeared, he delivered his case with 'expressions very high' (20October). Lilburne's subsequent release in early November alarmed sections of parliament, particularly in the Lords, who complained at not having been informed of the decision to set him free. ${ }^{130}$

The distrust of Lilburne among the 'Royal Independents' was soon justified, as he quickly redoubled his efforts against parliament. Within a matter of days of his release, the Agreement of the people was vexing the Lords (who ordered a declaration in response), and Lilburne began developing a well-organized network of friends and agents to mobilize support and organize propaganda. ${ }^{131}$

\footnotetext{
122 J. Lilburne, Two letters: the one from Lieutenant Colonell Fohn Lilbourne to Colonel Henry Martin (1647), sigs. A-Av; A Perfect Diurnall, 2 I3 (23-30 Aug. I647), p. I 7 I4.

${ }_{123} \mathrm{PRO}, \mathrm{SP} 28 / 46$, fo. I I 8.

124 Lilburne, Two letters writ by Lieut. Col. Fohn Lilburne, p. I.

${ }^{125}$ Perfect Occurrences, 37 (Io-I 7 Sept. I647), p. 253.

126 A Perfect Summary, 9 ( (1 $3^{-20}$ Sept. I647), p. 70.

127 Peacey, 'Henry Parker', pp. 242-3.

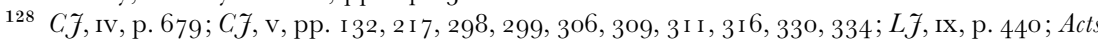
and ordinances of the interregnum, I642-1660, ed. C. H. Firth and R. S. Rait (3 vols., London, I $89 \mathrm{I}-\mathrm{I} 90 \mathrm{I}), \mathrm{I}, \mathrm{pp} . \mathrm{I02} \mathrm{I}-3$; W. Ball, $A$ brief treatise concerning the regulating of printing ( $\left.{ }^{6} 65 \mathrm{I}\right)$.

129 Perfect Occurrences, 40 (I-8 Oct. I647), pp. 275-6.

${ }^{130}$ Perfect Occurrences, 42 (I 5-22 Oct. I647), pp. 292-6; CF, v, p. 334; Lf, rx, p. 5 I I Perfect Occurrences, 45 (5-12 Nov. I647), p. 305, sig. Xx2; Perfect Diurnall, 223 (I-8 Nov. I647), p. I 789; Perfect Diurnall, 224 (8-I5 Nov. i647), p. I 799; Lilburne, Additional plea, pp. I 7-22.

${ }^{131}$ LF, Ix, p. 529; J. Lilburne, A defiance to tyrants (i 648 ).
} 
Such tactics simply provoked further delays in the consideration of Lilburne's business, ${ }^{132}$ and when the Presbyterian minister, George Masterson, provided eye-witness evidence regarding Lilburne's meetings, and the extent to which his friends were organized (I8 January I648), the response was swift and severe. After Lilburne had delivered a 'tedious answer', his bail was withdrawn, and he was returned to the Tower. What is interesting about the action taken in early I 648 is that it was masterminded for the first time by Independents rather than Presbyterians. Lilburne was no longer of any use to those who had previously sought to protect him, and had become a powerful enemy, against whom resources had to be marshalled. The secretary of the Derby House committee, Walter Frost, was delegated to issue a refutation of the Levellers' position, and Masterson's account was quickly published. ${ }^{133}$ These works were intended to coincide with a trial, the Commons having appointed some of Lilburne's old allies - including John Bradshaw and Gabriel Becke - to head the prosecution in King's Bench, ${ }^{134}$ while Henry Parker, from whom Lilburne had learnt so much, sought to distance himself from his putative pupil. ${ }^{135}$ The events of January i 648 represent, therefore, the final nail in the coffin of a relationship between Lilburne and the 'Royal Independents' which had been damaged irreparably in 1646 . Lilburne now attacked the political grandees with renewed venom, and began to rewrite his own history to deny that they had ever been his friends. ${ }^{136}$ Lilburne, along with other contemporaries, clearly regarded Cromwell as being allied with this group of aristocratic grandees. The royalist author of Mercurius Pragmaticus styled Cromwell and Saye 'the two fathers of the faction', ${ }^{137}$ and in May I648 Lilburne attacked 'Oliver Cromwell and other his Spaniolised creatures', claiming to have detected an alliance between parliament and the army grandees. Cromwell was now styled 'that usurper tyrant, thief, and murderer', and Lilburne highlighted the way in which Cromwell had joined forces with Manchester, the man he and Lilburne had originally tried to impeach. ${ }^{138}$

\section{IV}

It is at this point, in the spring of ${ }_{1} 648$, that it is possible to say that Lilburne had become the pariah who is familiar to conventional accounts. Lilburne's subsequent story was one of a desperate struggle for assistance from a disparate and increasingly powerless group of men. Although he was not without success

\footnotetext{
132 Perfect Occurrences, 50 (10-17 Dec. I647), p. 348; Perfect Occurrences, 54 (7-14 Jan. I648), pp. 372,376 .

133 Peacey, 'Henry Parker', pp. 2 I I-I3; W. Prynne, The Levellers levelled (1647).

${ }^{134}$ Cf, v, pp. 452, 536; A Perfect Diurnall, 234 ( 1 7-24 Jan. I648), pp. I684-6.

${ }^{135} \mathrm{H}$. Parker, Of a free trade ( 1648$)$, pp. I-6.

136 Kingdomes Weekly Intelligencer, 259 (2-9 May I648), p. 935; J. Lilburne, A whip for the present House of Lords ( 1648 ), pp. 2-3; J. Lilburne, The lawes funeral (1648), p. 2; J. Lilburne, The prisoners plea (I648). 137 Mercurius Pragmaticus, 3 (I I-I8 Apr. I648), sig. C2v.

${ }^{138}$ Lilburne, Prisoners mournfull cry, pp. 7-8.
} 
in garnering favour from both royalists and republicans, little was achieved by way of constructive help. While Lilburne's later years repay scrutiny, this piece will hopefully have contributed to our understanding of his career by placing him within the context of English politics in the I640s, and by reassessing the extent to which he was 'ungovernable', and in perpetual conflict with the governments under which he lived. This reading suggests that Lilburne's increasingly radical political theory, while real, was less significant for explaining his career during the first Civil War than his involvement in the arcane and Byzantine proceedings at Westminster. By stripping away the layers of propaganda with which Lilburne covered his own story, and by discounting a retrospective analysis, it is possible to show the extent to which he had worked with the political Independents, and the extent to which they had sought to protect him. During the mid-i64os the Independents had certainly exploited Lilburne, but he also formed part of their alliance, which was able to encompass men with differing, and more or less radical, views. The story of Lilburne's split from the Independents is not one which centres on him becoming more 'radical', or indeed on his allies becoming more 'conservative'. Rather, it is a scenario in which 'radical' and 'conservative' members of the Independent alliance drifted apart. It was only during the second half of I 646 that Lilburne broke with some of the more 'conservative' members of this group, in an indication of the progressive fracturing of the alliance which would take place over the following two years. Lilburne probably turned on the Lords in part because he felt personally betrayed, and it was his dismissal of their authority which caused the rift with his former allies. By accusing the peers of tyranny, and by challenging their jurisdiction, Lilburne not only alienated his aristocratic friends, but their allies in the Commons. It was Lilburne's breach with the Lords, rather than the Leveller opposition to 'parliament', which proved fatal. By refocusing his story in this way, it is possible not just to contribute to our understanding of Lilburne, but to enhance the picture of parliamentary politics in the 1640 s, in all of its complexity, and with all of its shifting alliances and machinations in both Houses. 